This item was submitted to Loughborough's Research Repository by the author.

Items in Figshare are protected by copyright, with all rights reserved, unless otherwise indicated.

\title{
And then came Brexit: experiences and future plans of young EU migrants in the London region
}

\section{PLEASE CITE THE PUBLISHED VERSION}

https://doi.org/10.1002/psp.2122

\section{PUBLISHER}

(c) John Wiley \& Sons, Ltd.

\section{VERSION}

AM (Accepted Manuscript)

\section{PUBLISHER STATEMENT}

This is the peer reviewed version of the following article: LULLE, A., MOROSANU, L. and KING, R., 2018. And then came Brexit: experiences and future plans of young EU migrants in the London region. Population, Space and Place, 24 (1), e2122, which has been published in final form at https://doi.org/10.1002/psp.2122. This article may be used for non-commercial purposes in accordance with Wiley Terms and Conditions for Use of Self-Archived Versions.

\section{LICENCE}

CC BY-NC-ND 4.0

\section{REPOSITORY RECORD}

Lulle, Aija, Laura Morosanu, and Russell King. 2019. "And Then Came Brexit: Experiences and Future Plans of Young EU Migrants in the London Region”. figshare. https://hdl.handle.net/2134/35577. 
And Then Came Brexit: Experiences and Future Plans of Young EU Migrants in the London Region

Aija Lulle, ${ }^{1}$ Laura Morosanu ${ }^{2}$ and Russell $\mathrm{King}^{3, *}$

${ }^{1}$ School of Global Studies, University of Sussex, Brighton, UK

${ }^{2}$ Department of Sociology, University of Sussex, Brighton, UK

${ }^{3}$ Department of Geography, University of Sussex, Brighton, UK

\section{ABSTRACT}

Under the umbrella concept of New European Youth Mobilities and its epistemological focus on the spatio-temporal entwining of intra-EU migration and youth-to-adult life transitions, this paper investigates the potential rupture that the UK's 'Brexit' referendum of 23 June 2016 might bring about in youth mobilities. In many respects, and counter-intuitively given the Brexit result, London has already become a 'Eurocity': a magnet for young people, both highly-educated and less-educated, from all over Europe who, especially since the turn of the millennium, have flocked to the city and its wider region to work, study and play. Now these erstwhile open-ended migration trajectories have been potentially disrupted by a referendum result that few anticipated, and whose consequential results are still unclear. The main theoretical props for our analysis are the notions of 'liquid migration', 'tactics of belonging', 'whiteness', 'privilege' and 'affect'. Data are drawn from 60 in-depth interviews with Irish, Italian and Romanian young-adult students and higher- and lower-skilled workers, carried out in late 2015 and early 2016, plus 27 re-interviews carried out in late 2016, post-Brexit. Results indicate participants profound and generally negative reaction to Brexit and, as a consequence, a diversity of uncertainties and of plans over their future mobility.

Keywords: youth mobilities; Brexit; London; liquid migration; privilege; affect

\section{INTRODUCTION}

In his seminal book Liquid Modernity, Zygmunt Bauman (2000: viii) argued that 'forms of modern life may differ in quite a few respects - but what unites them all is precisely their fragility, temporariness, vulnerability and inclination to constant change'. We find Bauman's observation particularly useful for theorising the New European Youth Mobilities in the context of Brexit. Geographers and other social scientists have recently made several advances in the study of 'liquid migration', an offspring of Bauman's liquid modernity (see e.g. Engbersen and Snel, 2013; Bygnes and Erdal, 2017; King et al., 2017). Liquid migration has the following key features: youth-adulthood transitions are predominantly work and study driven, are envisioned as temporary, are mainly invisible due to open borders, hence they are legal, and are spontaneous and unpredictable. Their defining characteristic is intentional unpredictability (Engbersen and Snel, 2013).

In the literature on youth life-course transitions, two concepts are important for our analysis in this paper. On the one hand, the 'inclination to constant change' referred to in Bauman's quote above is advanced by Worth's (2009) notion of youth and young-adulthood as a continuous process of 'becoming': we see this as more relevant and appropriate to our

\footnotetext{
${ }^{*}$ Correspondence to: Russell King, Department of Geography, University of Sussex, Brighton BN1 9SJ, UK. Email: R.King@sussex.ac.uk
} 
analysis than the traditional practice of age-defined life-stages. On the other hand, the reality of sudden changes due to 'fragility and vulnerability' (Bauman again) is nicely highlighted in the term 'rupture' (Hörschelmann, 2011). Taken together, the notions of 'rupture' and 'becomings', combined with the framework of liquid migration, constitute a useful conceptual toolkit for understanding the social and spatial mobilities of young EU citizens, both before and after the referendum of 26 June 2016, which saw 51.9 per cent vote 'leave' ad 48.1 per cent 'remain'.

According to Bauman, the key to the puzzle of liquid modernity is the premise that the 'liquidity versus solidity conundrum' is not a dichotomy but that both conditions should be seen and treated as a couple 'locked by a dialectical bond' (2000: $\mathrm{x}$ ). We see evidence of this dialectic emerging in our research findings, to be presented in more detail later. Here, we briefly mention some relevant macro-context. The 'free movement' institutional arrangements of the EU paved the way for fluid mobilities which gave EU citizens both the 'privilege' of looking for work and study opportunities and a better life elsewhere within Europe, and a kind of 'invisible' status as 'white, European, legal' migrants (Engbersen and Snel, 2013). However, the recent 'shock' event of the Brexit vote threw this privilege into question. At the time of writing (February 2017) the rights of EU migrants to stay on in the UK have yet to be granted by the British government, so it is uncertain how free movement and privileged status will express themselves in the near and long-term future. For now, and in this paper, we focus on EU migrants' reactions to Brexit and on what they see as their options for the future. To be more precise, our overarching research question is to understand the meanings that young Europeans in the London area attach to their mobility motivations, experiences and future plans in the light of the referendum result. We strategically choose three contrasting national groups - Irish, Italians and Romanians - to explore these reactions, meanings, experiences and plans.

\section{IRISH, ITALIAN AND ROMANIAN MIGRANTS IN THE UK}

According to the Office for National Statistics (ONS, 2016a), around 3.2 million migrants from the EU live in the UK: 83 per cent hold an EU nationality, 16 per cent have British nationality and 1 per cent are non-EU nationals. On the criterion of birthplace, Poles are the largest foreign-born population in the UK $(831,000$ in 2015), whilst Irish come fourth $(382,000)$, Romanians $(220,000)$ sixth and Italians $(162,000)$ twelfth. Of the other top-ranked nations, Indians and Pakistanis are second and third, and Germans fifth. Hence, our three chosen study-groups are among the top five groups of EU migrants in the UK in 2015 (ONS, 2016b).

The Republic of Ireland joined the EU in 1973, along with the UK and Denmark. However, the Irish have a very special status and migration relationship to the UK. Ireland is a part of the free travel zone within 'these islands'. Irish citizens can vote in UK national elections, and were also able to vote in the EU referendum. And yet, due to the long history of Ireland as a relatively poor country and as a nearby pool of English-speaking labour, historic and ongoing power relations in terms of subordination were explicitly narrated by some of our informants. Therefore, despite being formally the most privileged of our three migrant groups - being able to travel freely, access jobs and benefits, and also vote - the selfdescription is much more ambiguous in the case of Irish, as we will demonstrate later in the paper.

Italy is a founding member of the EU, symbolically emphasised by the Treaty of Rome (1957), and emigration, both to the UK and other destinations, is long-standing. During the 1980 s and 1990s, Italy reversed its migratory balance and became an attractive target for 
immigrants (King and Andall, 1999). However, during the 2000s, and especially since 2008, economic recession and lack of opportunities have pushed young and educated Italians to seek better lives outside their country of birth. In this more recent emigration, thanks to the expansion of easily accessible and relatively cheap air and road links, Italians, like many other Europeans, have enjoyed a kind of 'migrancy habitus' - a range of mobilities back and forth between Italy and other countries (Harney and Baldassar, 2006). Above all, Italians have enjoyed the privilege that is encoded into the notion of being 'old' EU migrants. Namely, they unquestionably belong to Europe; they founded the EU.

Unlike the Irish and Italians, Romanians are relatively recent migrants to Britain. They are part of the 'new' Europeans in the UK, whose countries only recently joined the EU in 2004 and 2007. Whilst they share many advantages with other EU citizens, two key factors have contributed to a markedly different experience. First, unlike their Western counterparts, who had been largely invisible in public discourse until recently (Favell and Nebe 2009), East European migrants have encountered a negative reception and press representation. Romanians have often made the headlines of (tabloid) news stories that associated them with crime, benefit shopping, pressure on jobs or public services (Fox et al., 2012). Second, Romanians' restricted access to the labour market was maintained until 2014, when the seven-year transitional period since joining the EU came to an end. The referendum outcome has thus thrown into question Romanians' only recently acquired full rights and status within the UK.

The brief historical and statistical description given above is just one aspect of the differences between our groups of inquiry. We need to probe deeper into how such degrees of 'privilege' may relate to responses to Brexit. Furthermore, we need to give nuance to the specificity of this 'privilege' in terms of liquid migration and the potential ruptures brought about by political events, and discuss the more ambiguous position of East Europeans compared to West Europeans. Politically, the context of growing nationalism and populism, and the 'affect' that the event of Brexit projected into the emotional and bodily experiences of our informants, equally demand our attention.

In what follows, we will first outline the theoretical framework of how to advance the notion of liquid migration through a better understanding of 'privilege', potential 'ruptures' and affective responses to these. This will help us to understand the meanings that our participants attach to their experiences of mobility and migration. A section on methodology then follows. Analysis of our interview data is in three parts: the original migration motivations; the affect of Brexit; and future plans in an ongoing climate of uncertainty. In the conclusion we return to the theoretical puzzle of liquid migration and potential ruptures of youth mobilities.

\section{THEORETICAL FRAMEWORK}

Although studies on 'liquid migration' have yet to incorporate a focus on youth transitions, the very notion of liquidity seems well-suited for understanding the non-linear transitions and life-courses often associated with contemporary youth, whose passage from school to work, and work to full adulthood and establishing home, is often complex, reversible or overlapping (Du Bois-Reymond and López-Blasco, 2003; Walther et al., 2006; Blossfield et al., 2012; Lundahl and Olofsson, 2014). In the context of Brexit, such transitions are best scrutinised through the notion of 'rupture' (Hörschelmann, 2011), and this rupture has distinct political and personal dimensions. Diverse European youth mobilities were previously enjoyed as legally entitled rights, which privileged EU migrants over those from non-EU countries, but the sudden yet still painfully ongoing political rupture threatens to take rights and privileges 
away. We want to understand how the privilege of 'liquid' - relatively free - mobilities within the EU may be perceived, experienced, or feared to become lost - 'solidified' - due to Brexit.

Furthermore, through our comparative approach, we also want to document the different meanings of 'privilege' among three groups of intra-EU migrants. In order to do so, we place this question into a broader literature on 'whiteness' (see, e.g., McDowell 2007, 2009; Parutis 2011; Fox et al., 2012). Our contribution is to build on this literature to further explore the little-known spatio-temporal modalities of intra-EU migrant hierarchies and a variable sense of privilege, and to do so from the migrants' perspective. We see 'whiteness' in relation to racialised self-identification and social hierarchies through which some Europeans are seen as more 'valuable' or entitled to privileged treatment than others. But what are the geographical, national, and power relations underpinning such hierarchies? And how is this sense of privilege reconfigured in the context of an abrupt political change? The possibility of Britain leaving the EU is that these migrants' previous relative 'whiteness' and 'Europeanness' no longer ensures the privileges of free mobility and public acceptance, which have been enjoyed by 'old' (i.e. pre-2004) EU migrants for several decades. The whole concept of liquid migration is based upon the premise that Europeans have the privilege of social and geographical mobilities within the EU. And yet, the subjectivities of privilege, based in particular on nationality and ethnicity, did not melt away during the free movement regime.

For many, the rush of events in 2016 and the surprise result of the referendum came as a shock - an affective state. Not only were nationalist and populist slogans sparked off among the British; the revision of hierarchies of 'whiteness' and 'worthiness' provoked intense emotional reactions amongst our informants too. In connection to this, we want to bring in the recent geographical debate on 'affective nationalism' (Antonsich and Skey, 2016; Merriman and Jones, 2016) and what some authors call 'affective atmospheres' (e.g. Wetherell, 2013; Anderson, 2016). Merriman and Jones (2016) use the notion of 'affective nationalism' to stress the intermittent, emergent and relational character of 'nation', which creates affective manifestations of nationalism. Antonsich and Skey (2016:1) further draw attention to uneven power relations, which 'mediate the capacities of human bodies to affect and be affected', and call upon people's agency to be attended to more carefully in order to capture the dimensions of affective nationalism. They distinguish between conscious cognitive and discursive affects versus unconscious ones. These latter, for instance, can be felt in the body but may lack words to be explained and reflected about. Antonsich and Skey (2016: 3) also stress the historical formations and future orientations ('foregrounding and backgrounding' in their words) that give rise to affective nationalisms, as well as making the more conventional distinction between 'hot' (armed, security and threat-related) versus 'banal' (flag-waving, celebrated) nationalisms.

While pro-Brexit supporters were celebrating the 'independence' of Great Britain and 'taking back control of our borders', European migrants, who were at the core of the referendum debate, also experienced these affective nationalism atmospheres, yet quite differently in most cases, through their transnational emplacement but also exclusion, because Europeans migrants could not vote, except for the Irish. Although, ironically, the referendum was in many respects about 'them', they had no right to vote as EU citizens, unless they held an Irish or British passport. Nevertheless, European migrants do have some elements of agency and are able to express various forms of resistance.

In this respect, we find it appropriate to talk about migrant 'tactics' (de Certeau, 1984; Scott, 2013). ${ }^{1}$ De Certeau argued that the ordinary people equip themselves with a weapon

\footnotetext{
${ }^{1}$ The migration literature often uses the term 'strategies', as in 'coping strategies' (e.g. Snel and Staring, 2001; Kosic and Triandafyllidou, 2003). In the theoretical distinctions proposed by de Certeau and Scott, the strategic
} 
which he calls a tactic. In this formulation, 'tactics' were the tricks or the arts of the weak the 'last resort' of the weak that 'helps them to inscribe displacements in the prevailing order for its reorganisation' (de Certeau, 1984: 37). Scott (1985), on the other hand, insisted that 'weapons of the weak' have a considerable power to impact and even subvert power structures, as acts of resistance are not the 'last resort' but practised and tightly knit into everyday encounters.

\section{METHODOLOGY}

This paper is explicitly comparative. It compares three immigrant nationalities, and their migration motivations and future plans before and after the Brexit vote. The principal method used to gather data is the in-depth semi-structured interview, carried out with purposivelydrawn quota-samples of young adults who were aged 18-35 at the time of migration to the UK, and aged up to 39 at the time of interview. All interviews were with participants who lived and/or work/studied in the London region, which was defined loosely as the conurbation itself plus other towns within a roughly one-hour commutable distance. The three national-origin groups were strategically selected to represent different histories of migration to the UK, different historical-political relationships to Britain and the EU, and different perceptions of how migrants are positioned with respect to British society, as explained earlier.

Sixty interviews (20 with each national group) were carried out in late 2015 and in the first half of 2016, before the referendum. These interviews were distributed relatively evenly across students, higher- and lower-skilled workers and were approximately equally split between men and women. The main focus was on reasons for migration, experiences of work and life in the UK, and plans for the future. For those interviews carried out closer to the referendum date, questions were also posed about attitudes towards possible outcomes of the referendum. Follow-up interviews with several participants from each national group were conducted in Autumn 2016, a few months after the referendum. This subsample of 27 comprised 8 Romanian, 9 Italian, and 10 Irish migrants. The re-interviews focused on reactions to the Brexit outcome, with particular reference to future plans. Whilst the main interviews averaged 50-60 minutes in duration, the re-interviews were generally shorter, 2030 minutes. All interviews were conducted in migrants' native language, recorded, and transcribed directly into English by researchers fluent in both languages, in order to enable cross-group comparative analysis. This centred on three key themes: motivations for migration, migrants' 'affective' responses to the EU referendum outcome, and their more tactical considerations about future work and settlement post-Brexit.

\section{FINDINGS}

We begin our analysis of results from the interviews with some general background findings. The role of the 2008 financial crisis and its lingering aftermath had a variable impact as a push-factor for migrating to Britain. It was important for many of the Irish sample (given the suddenness and depth of the Irish recession), but less impactful for the Italian sample, whose members spoke of a more general structural crisis in Italian society, with minimal

level is ultimately linked to political and economic powers, which set structural rules for socio-economic relations and the spatial order. 'Tactics' are more micro-level steps taken by individuals and groups to redress unequal power relations and positionings. 
opportunities for career advancement in many employment sectors and professional fields (see also Conti and King, 2015; Tintori and Romei, 2017). For the Romanians too, concerns about limited career prospects or possibilities to 'build a future' at home were also widely narrated, especially amongst the higher-skilled; whilst sheer economic hardship was a more prominent driving force for the Romanian lower-skilled.

Whilst the Irish were able to trade on their native-English language knowledge, for some Italians and Romanians, the limited recognition or transferability of home-earned qualifications and their weaker language proficiency likely explain the difficulty to access jobs commensurate with their qualifications, resulting in de-skilling for many, at least for a time. However, across all three national groups we find stories of people who have significantly advanced their material wellbeing and careers by moving to the London region, including some who would fit the Favell (2008) 'Eurostar' ideal-type - highly educated, multilingual professionals, in good jobs in finance, engineering, marketing, the media, and academia. Many interviewees also spoke at length about what they saw as the multicultural, open, and meritocratic ambience of London and its labour market, which offered them career and lifestyle opportunities far beyond what could be achieved in their home countries.

Those first-round interviews which took place in the weeks and months leading up to Brexit, when the referendum date was already known, contained substantial discussion on possible outcomes. In these pre-Brexit interviews, three narrative themes emerged as recurrent. The first was the belief that 'Brexit' would not happen: surely the British people would not be so 'illogical' as to vote for something that was predicted to cause significant harm to the British economy! Second, Italian and Romanian interviewees bemoaned the fact that, although the referendum was, in large part, about 'them' as EU immigrants in Britain, they were denied a formal political voice and, moreover, implicitly declared 'unwelcome'. The Irish could vote, as a result of the special political relationship between Ireland and Britain. The third narrative theme in these pre-referendum interviews was what we call 'tactics of belonging' - a discourse and set of actions through which interviewees stressed their right to 'belong', their contributions to the British economy and society, and the ways in which they felt 'at home' in London or other places nearby where they lived. Some of these issues are picked up for further comment in our analysis of the post-referendum interviews.

We begin the rest of our analysis of our main findings with a section on migration motivations and youth transitions as perceived, experienced, and anticipated before Brexit. Then, we examine the extent to which participants' experiences are marked by the 'rupture' produced by the referendum result and the affective (i.e. bodily and emotional) responses to it. The third section will focus on migrants' tactical considerations regarding their future plans, in the light of both pre- and post-referendum motivations.

\section{Migration motivations}

Work and study were the most recurrent motivations for migration invoked by our research participants. The perceived 'temporary' nature of their stay and an 'intentional' openness towards the future underpinned most of the interviews, in a clear evocation of the principle of 'liquid migration' as described earlier. Even if many young Europeans felt reasonably settled in the UK, the privilege of open borders did not exclude the possibility of future migrations. Youth unemployment has been a pan-EU concern for years, which became all the more pressing since the economic crisis hit several EU countries. Unemployment among youth under 25 was 20.9 per cent in 2015 (Eurostat 2016), rising to double that rate in Italy (40.3 per cent). Hence, lack of work, and even more, career opportunities for the skilled, constituted a key driver for many who came to the UK. 
When comparing our three groups, not only did the Irish emphasise their intentions to remain temporarily in the UK, they were also more experienced in global migration and more open to future migration than the two other groups. Cian (27), for example, came to London to do his second Master's degree in a prestigious university. Prior to arriving in London at the age of 26, he had already gained work experience not only in Ireland but also in South Korea and Australia. And yet, upon his return to Ireland, work opportunities were rather scarce and, without much thinking, he boarded a plane to London, quickly found a place to live with other Irish friends, and started his studies and two part-time jobs. He did not have plans to stay in London for a long time beyond the one-year degree programme; maybe a couple of years more, if work and life turned out to be exciting. Brexit was not a concern for him:

I am not particularly worried about it, to be honest. I think that has to do with Ireland's particular relationship with the UK. In terms of travelling and working, it has always been on a different scale than the rest of the European Union... I will be fine.

Cian's words emphasise his peace of mind, due to the formally highest privilege, given only to Irish citizens among all EU migrants. Unlike the rest of our informants, Cian expressed his scepticism towards the EU. Most of the other Irish informants expressed worries prior to the referendum, because they staunchly supported the idea of togetherness in the European Union. Whatever the referendum results would have been, however, the Irish felt 'safe' in terms of working, studying, leaving or returning the UK. ${ }^{2}$

Young Italians emphasised career prospects and meritocracy as their main motivation for migration. Alessandro (22), who came for study reasons but got a professional job too, put this dominant motivation succinctly:

I don't want to sound like a fanatic but I would never have found such a job in Italy, so... It [a professional job] has given a different meaning to my staying here.

Other reasons are also evident in Italians' stories. For the lower-skilled, the typical path was coming to work in Italian businesses in the UK, most notably in restaurant chains where they might initially be exposed to long working hours and lower pay due to lack of language and bureaucratic skills to assert their rights. For others, learning English, being away from parents, and wanting to grow as independent individuals were the motivating channels leading them to London and surrounding areas. Elisa (36), for instance, came to work in the restaurant trade in Brighton. Her intermingled motivations unfold in this longer excerpt:

I came to the UK at the age of 33. It's crazy because you are old, who gives you a job at 33? [And...] to be fair, it happened quite randomly. Meaning, the catering firm I was working for had some connections, it was trying to build some connections here, to open some branches. They asked me if I could move to the UK, because they would shortly open a branch. So, without knowing the language, I said, 'Ok!'. At least I will learn a new language. (...) I came to a country where there is meritocracy. (...) I voted for Brighton and Hove City Council [i.e. in local elections], I pay my council tax and I'm very happy to pay $£ 70$ per month, because I get it back in terms of

\footnotetext{
${ }^{2}$ However, this formal sense of being 'safe' is not exclusive to all Irish migrants. Several had partners or cohabited with third-country nationals or EU nationals, and therefore the possibility to lose the privilege of free mobility across borders became a 'family' worry.
} 
services. Here everything is simpler, less bureaucratic, less twisted... I work, and I am happy.

Elisa's spontaneous move to the UK not only provides a vivid illustration of 'liquid' migration and reflects the close interconnectedness within the EU, including business links, but also demonstrates her aspirations for self-development and higher satisfaction with her life in the UK compared to Italy. This corresponds to the argument of Bartolini et al. (2016) that emancipation is one of the key motivations in the case of contemporary Southern European migration northwards.

Our Romanian participants' decision to migrate was similarly motivated by the study and work opportunities available in Britain, and London in particular, compared to their home country but also compared to other key destinations for Romanian migrants, such as Italy and Spain. Stories of economic hardship, insecurity and the difficulty of finding decently remunerated jobs at home were a commonplace. Crina (31), who left after completing the first year at university in Romania, provides a telling example of the financial difficulties that compelled many to migrate:

My parents had to support me during my studies. It was impossible. I did not have to pay university tuition fees but a lot of money was still needed, and no one employed me. It seemed impossible to me. I don't think anyone employed students with no experience during that time... not even to serve food.

Even those who earned 'good' salaries at home invoked the constant struggle to cover daily expenses, whilst others who had just finished school saw limited chances to fulfil their professional aspirations in Romania. These motivations were often combined with opportunities made available by friends or acquaintances abroad, as well as the desire to 'see the world', have new experiences, and become more independent, echoing the openness and flexibility characterising European youth's 'liquid migration' more generally. Georgiana (35), for example, had worked in tourism and travelled frequently before coming to the UK in 2007. Although she felt attached to London and saw her future there, she also described herself as 'adventurous' and 'very open' when talking about her migration decision and experience:

If I am not well in a place, I would leave for sure. I wouldn't think about it twice... Oh, you are tied to the land or.... No. You are tied to absolutely nothing on this planet.

In sum, the freedom and flexibility enabled by intra-EU 'liquid migration' was the main attraction for these young mobile Europeans. At least for the Irish and Italians, being 'liquid' for many years meant relative ease in making the decision to go to the UK and to remain there if things go well, or to move away if they do not. Another characteristic feature of intra-EU 'liquid migration' is the way spatial mobility intertwines with social mobility through higher-level study and progressively better employment experiences. As Parutis (2011) found in the case of Polish and Lithuanian migrants in Britain, many of our working migrants too have gradually moved from 'any' kind of job, to a 'better' one, and even to their 'dream' job in some cases, and therefore 'solidified' their careers and 'earned' their superior jobs thanks to the privilege of EU free movement. Unlike their Irish and Italian counterparts, Romanians' flexibility was considerably constrained by the seven-year transitional work restrictions, lifted only in 2014, although most participants managed to secure more stable 
positions over time, and students generally enjoyed easier access to employment right after Romania joined the EU.

However, our participants' privileges suddenly became unsettled on 23 June 2016, albeit to various degrees for the different national and 'skills' groups. The above-mentioned themes of rights to belong, meritocracy, and the straightforwardness of everyday life in the UK emerged with greater resonance in the post-Brexit re-interviews. In what follows, we discuss the effect of the Brexit vote on our participants in both practical and affective terms. The deeply-felt political 'rupture' produced by the referendum result powerfully underscored the salience of emotional and bodily 'affect' (Anderson, 2012, 2016). What seems to have happened is that the referendum - both in the debate leading up to it and since - brought the hitherto relatively 'invisible' European migrants into the spotlight, exposing new hierarchies of privilege amongst 'white' Europeans and reconfiguring divisions between 'us' (British) and 'them' (Europeans) and between 'old' and 'new' Europeans.

\section{The affect of Brexit}

Although the migration trajectories of the young Europeans we interviewed were often openended, given their age and early-adult life-stage, their potential choices have undoubtedly been sharpened by the referendum result.

We noted above that the Irish are technically 'unaffected' in their free movement privilege; even so, our research participants experienced the 'othering' very sharply:

When the results happened... I remember it as a punch, as a real shock. I was in Cornwall with my family and I was pressing buttons on the TV remote, and the news was the first thing I saw in the morning. And I cried. It was that shocking. I mean that I completely felt shocked: 'Why, why do they hate us?' (Rachel, 25).

I was really surprised by my response actually, by my kind of emotional response which seemed very involuntary. I was really taken aback, I think. I kind of felt it was a victory for disconnection between people. Which in general I feel like a terrible thing, but also I actually felt myself like kind of personally offended. I thought, 'Fucking hell. There are actually people who don't want me to be here?!' (Daniel, 27).

What we particularly want to highlight here is the role of 'affective nationalism' that emerges in encounters with 'others', and the 'national' and 'ethno-national' dimensions that are embodied in specific events. Militz and Schurr (2016) draw on feminist writing to explain how bodies are affected differently by nationalism, especially in its material manifestations such as flags and other national symbols. But what we need to highlight here is not only this material dimension - British flags, British symbols - that 'other' the Irish too, but the very exclusive nature of manifestations of affective nationalism. The Brexit result was celebrated by the British who voted 'leave', but there was no shared sense of victory with the privileged Irish, although they could keep their mobility privileges. On the contrary, the Irish informants emphasised the affective dimension of a shared 'migrant' identity with Europeans and other migrants who have long been seen as 'others' in Britain due to their skin colour or ethnicity. One of the Irish student participants, Sandy (22), showed outright anger at the Brexit outcome:

For some reason the 'leave' vote has justified racism, and all the massive xenophobes out there and suddenly they think it's ok. Who are they to tell a Muslim to go back to 
their own country or tell a Polish person to go back to their own country? They would never dare say it to me. They would never dare say it to an Australian person. Because I look the same as them? So they're not afraid of me? It just makes me so angry. It's so unfair. I can honestly say that if someone told somebody to go back to their own country in front of me....oh...I'd have a lot to say!

Moreover, affect reaches further than the materiality and sociality of certain events. The Italian quote that follows illustrates how the painful events related to the very ground of the Italian 'homeland' were affectively linked to the unstable 'political ground' of post-Brexit Britain. In 2016-17 Central Italy was shaken by earthquakes - a seismic geological possibility abruptly came a reality. Elisa, whom we introduced in the previous section, articulated her affective responses by projecting the painful feelings experienced in relation to the natural disaster that had shaken her home country onto the 'political earthquake' of the referendum result, which disturbed the calm of her current life in the UK:

I woke up at $6.30 \mathrm{am}$ and I...I had a breakdown. I will remember that day as...I don't know how to say this, it's like...Before an earthquake you have the feeling that there is something weird...Apparently nothing happens but, before an earthquake, but literally, seconds before, everything is still, you hear an incredible silence and, at a certain point... boom! - the blast.

Her narrative goes on to emphasise the negative emotions of anger, consternation, and rejection experienced during the days that followed the referendum:

The Euro Cup [football] was going on, England played against Italy...we used to go out, we used to go to a pub, so we went out, we met other British...the feeling was that 'You don't want us anymore...' And the very same morning of the referendum I heard from the streets - it was June, so the window was open - I heard that in my alley a girl - she was young - was screaming 'Happy Independence Day to you! Happy Independence Day!' to everyone passing by. And in that moment I opened the window and I yelled at her 'Shut up!' but with such an anger... you try not to, but you take it personally. And you think 'What have I done to deserve this?' Because, clearly it was not a vote on the EU, it was a vote on immigrants.

Closs Stephens (2016), who analysed the 'happy atmosphere' during the Olympic Games in London in 2012, has emphasised the need to disentangle the relationship between affect and politics, which results in the creation of national affective atmospheres. This constellation of politics, affect and nationalism raises an important question of understanding how such an 'unhappy atmosphere' might be resisted. One answer is clear from the Irish data, referred to above: the juxtaposition of historical 'othering' and ascribed 'migrant' status on the one hand, and the privilege of free mobility on the other, did not draw our young Irish informants into the 'happy atmosphere' of the Brexit supporters. In the Irish case, the resistance to the realities of Brexit rather translated into anger towards the politicised climate and exclusionary politics of the UK, and solidarity with other migrants. Some of the Irish interviewees voiced worries about the knock-on economic impact of Brexit on Ireland, and about the possible reemergence of a 'hard' border between Northern Ireland and the Republic.

By contrast, in some of our Italian participants' accounts, the resistance to Brexit celebrations translated into value judgements that drew hierarchies amongst migrants. We 
continue with Elisa's narrative, which referred to an after-referendum encounter with a 'British gentlemen', a stranger to her, who mentioned the word 'immigrant' 'constantly and at least 10 times' in their short chit-chat:

This thing of 'immigrant, immigrant, immigrant'...We are Italian and we are a certain kind of immigrant, A-rank immigrants. If you talk to someone who voted LEAVE [exclaimed] to clean his county from...you talk exclusively about people who you do not want: Romanians, Poles, Czechs, Slovaks and Turks! The main danger that people perceived, the reason they voted to leave, was the risk that the EU would accept Turkey and so that there would be an exodus from Turkey.

Not only was Elisa, a national of one of the EU's founding states, shocked to be swept into the broad category of 'immigrant'; she herself was using affective value judgements of migrant hierarchies and identity negotiations. In the Finnish context, historical and value judgements-based hierarchies of migrants have been studied by Koskela (2014), who revealed how 'Western' and 'highly skilled' migrants were seen as 'desirable' and occupied a privileged position in the hierarchies defining Finnish society, but also how migrants themselves internalised such hierarchies. As a result, unfair treatment is perpetuated politically and becomes internalised individually, reducing the possibilities to resist such hierarchies.

Shock at the referendum outcome was also the typical reaction of the Romanian participants, who expressed a sense of solidarity with other migrants. Ramona (21), for example, summarised her first reaction as 'shock and horror' at the entirely unexpected outcome, which 'totally change[d] the world history, turn[ed] it 180 degrees'. She described the more general atmosphere of dismay and distrust at her international workplace, where many were from Spain, Portugal and Italy, and sharp boundaries were suddenly drawn between them and the British, whose potential 'leave' voter status was regarded with anger and distrust:

The day the result was announced, everyone was very upset, shocked, and they [colleagues] were almost crying and, like, when they had to serve a Brit... we asked every single Brit if, how they voted...

Whilst some participants felt reassured and 'pleasantly surprised' by their work colleagues' and employers' encouraging words or apologetic behaviour, and many Romanian interviewees fervently hoped that Brexit would not affect those who were students, long-term residents, and economic contributors, an element of insecurity and vulnerability increasingly permeated their stories, especially when comparing the interview narratives before and after the referendum. Concerns about racism and negative sentiments against 'all migrants', not just Europeans, started to cast a shadow on their relatively settled lives in the UK. Some reported isolated, yet deeply uncomfortable, incidents of being told to 'go back to [their] country'. Others felt mistreated for the first time in years because they held Romanian passports when crossing the UK border. Or general worries about being seen and heard speaking a foreign language on the street demonstrated the deeply-felt emotional burden and negative atmosphere created by Brexit.

Nevertheless, these feelings of unease and consternation were not necessarily coupled with intense involvement in the Brexit debates. Although denied the right to vote in a matter that concerned them directly, Oana (21), one of the student participants, described herself as not having 'a protester spirit' and Brexit was not 'her fight': 
It was more their fight, they voted, they did it with their own hand. We did not have a right to vote, erm, we simply stayed and followed it from the shadow, so to speak.

The sense of relative lack of entitlement to participate in the referendum that transpires from this quote could be related to Romanians' recent arrival in the UK, the seven-year wait to acquire 'full' rights to work in Britain, and the wider political withdrawal and disillusionment with politics noted amongst migrants from post-communist societies.

Comparing the affective responses to the referendum that emerged from our interviews, it is interesting that the Irish, who had the right to vote, were the most vocal, even angry, at what they saw as a 'mistaken' decision, which also impacted upon them as they were made to feel less welcome as EU migrants in the post-referendum climate. For the other two groups, a kind of disbelief was mixed with more tactical considerations and plans for the future.

\section{Future plans and uncertainties}

In our final analytical section we link the 'liquid migration' motivations to the reconfiguration of future migration trajectories in the light of Brexit. When we attempted to recruit participants to re-interview, which took place less than a year after the first interview, we found that some of them had, in fact, already moved. This was not so much due to Brexit but rather to the permeating characteristics of temporality, opportunities for career progression, and changes experienced either in their private or working lives.

The Irish mostly stressed their desire for temporary migration. In typical responses, the future was envisaged as 'some years' in the UK, and then moving away. Eileen, 31, a graduate with specific expertise in Middle East affairs, said she was relieved that her office was being moved to Germany:

I think it [Brexit sentiment] is something really negative for the country. I am really glad that I will soon not live in the UK anymore. My organisation will have new headquarters in Berlin. I think I will never move back there [UK]. I don't want to live in a country that has those kind of sentiments. Even though I know there are other countries in Europe where this anti-EU sentiment is there, I find it really shocking.

Interestingly, despite the assumption that Irish are prone to move only to English-speaking countries, many considered moving elsewhere in Europe, and were open to learning and improving their knowledge of other European languages if necessary for work. ${ }^{3}$

For the Italian interviewees, future plans included learning to adjust, preparing for new hardships in the UK, but with the hope that they will continue to be valued by their employer. The possibility of returning back 'home' was revisited in a more positive light too.

Then I thought 'Let's finish this $\mathrm{PhD}$ in two years and let's see', I have a stronger incentive to do it. After that, it is not that I was planning to stay in the UK (Laura, 27).

\footnotetext{
${ }^{3}$ This resonates with research carried out during Ireland's earlier boom in graduate emigration, during the 1980s and early 1990s, when a clear 'European' orientation was evident alongside the traditional emigration destinations in Britain and North America. See King and Shuttleworth (1995) for the general picture of skilled Irish emigration at that time, and MacEinri (1989) and King and Arbuckle (1992) for case-studies of the Irish in Paris and Rome respectively.
} 
As the quote suggests, for Laura, the accumulation of educational capital comes first, and then she will reassess the environments where the translation of this capital would give the best chances of establing a fully independent 'adult' career.

Although some Romanian participants felt less involved or entitled to take part in the Brexit debates, they nevertheless asserted their right to stay in the UK as hard-working, documented, 'deserving' migrants. For example, Mia (25), who worked in a restaurant, explained her expectation of the opposite referendum outcome in relation to migrants' positive contribution to the UK:

We all thought that because we work with all the right documents, this won't affect us. Because we are not unemployed, we are not living off the state's benefits, we earn our money, pay our taxes, and we think everything is alright.

Emphasising their right to stay did not, however, mean they would necessarily stay in the UK. Indeed, until recently, few had considered anchoring themselves more firmly in the UK via obtaining permanent residence or citizenship, partly because the EU citizenship afforded them both the freedom to stay and delay more solid commitments. Whilst the prospect of losing these privileges forced many to consider the question of settlement more seriously, a cautious, 'wait-and-see' approach was often adopted, as Ana (37), an assistant accountant, explained:

If everything [changes], then of course my future plans will be affected... we can relocate if that is the case. Perhaps this is why we did not think about applying for citizenship very quickly. As long as you do not see the change, I am not sure it's worth it. I know Romanians who are here, they want to be legally here, but you can be legal with a residence card too. But to apply for citizenship, you first have to find out what the conditions are, if it's worth being a British citizen after Brexit and in the future. This is probably why we are not rushing.

This hesitation was also visible in some participants' concerns towards future work opportunities and possible discrimination against non-British applicants, which contrasts with the pre-referendum praise of Britain's open and meritocratic system. In this climate of insidious insecurity, the Romanian participants were prepared to 'adapt' and relocate, if needed, relying on their cultural capital but also on their accumulated skills related to migrating and living abroad, as Oana emphasised:

I won't be stubborn to remain here. If I can make a future in another place, why not? I have already moved from a country. I know what happens, I know what it means to move to another country, I've been there.

Contemplating the possibility of moving on, Dorina (24), who was a research analyst, saw the uncertainty about staying as her main worry but also revealed some excitement, echoing the positive challenge of 'liquid migration':

If they kick me out of England, it is not the worst thing ever, because I can go to Spain, somewhere warmer and sunnier...

Summing up, the following findings were recurrent in our three groups. For some, the trend to formalise ties to the UK has been intensified, especially for those in stable jobs 
and/or relationships which would tend to 'root' them more in the UK. Looking to the future, Moreh et al. (2016: 4) predict that naturalisation rates will increase as many EU migrants in the UK will want to acquire British passports. For others, their solution to Brexit was to envisage their own exit, either by returning to their home countries (which many had flexibly envisaged anyway, sooner or later), or by moving elsewhere within Europe to countries where the rights of free movement, work and residence seem more secure.

In terms of their ability to negotiate between the ideal of 'liquid' migration and the 'solidifying' effects of Brexit and its associated anti-immigrant political climate, participants of all three nationalities often tend to rely on their employers emotionally, and stress their progressive career histories of being 'good and 'valuable' workers. But they also fear that, under a 'hardening' political atmosphere, lay-offs of employees and fluctuations of labour demand could, in fact, become even more flexible, to the detriment of many. As Trenz and Triandafyllidou (2016) also envisage, flexible demands in the 'post-Brexit laboratory' would put the lower-skilled workers at higher risk of precarity.

\section{CONCLUSION}

We initially anchored this paper within the linked ideas of 'liquid migration' and 'youth mobilities', and the need to expand the application of this dual concept in the light of political 'ruptures'. Before we sum up our findings, let us return to Bauman (2000: ix), who argued that 'the quest for the solidity of things and states', or, in other terms, progress and growth, was 'most often triggered, kept in motion and guided by their liquefaction'. For our informants, the very idea of open borders for intra-EU mobility was to progress in their selfdevelopment, careers, earnings, cultural capital and education, as well as to contribute to growth in the UK, the country of their residency. The underpinning question is whether Brexit will 'solidify' (i.e. slow down, or even halt) European youth mobilities. Bauman's theory offers an answer as follows:

...liquidity was not an adversary, but an effect of that quest for solidity... If there is anything that permits a distinction between the 'solid' and 'liquid' phases of modernity (that is, arranging them in an order of succession), it is the change in both the manifest and the latent purposes behind the effort (2000: ix).

The nationalist and populist purpose behind Brexit slogans like 'British jobs for British people', and 'taking back control of our borders' signified an effort to sequence the phrases of 'liquid' migration and 'solidification' into a national (and 'natural') order of things: i.e. solidifying borders would staunch the 'liquid' flows. However, as we know from migration history, either the UK Immigration Acts in the 1960s, or Germany's 'Gastarbeiter-stop' in the 1970s, and other efforts elsewhere in the word, such attempts to control migration did not solidify migration flows but created new mobilities, such as migration for family reunification purposes and an increasing instrumental use of visitor and tourist visas.

Part of our contribution to the vindication of the Bauman thesis of the indissolubility of liquidity and solidity lies in our comparative interview survey approach. We have been able to demonstrate that, in the views and experiences of many of our informants, there is an intersecting progression between liquid migration and the 'solid' achievements registered in educational qualifications, cultural capital, career enhancement and business development. Another element of this paper's contribution at the conceptual level has been our argument that more nuance in our understanding of youth mobilities as 'becomings' (Worth 2009) could be achieved by bringing the effects of political 'rupture' and the underpinning 
historical and contemporary processes of hierarchy-making into the picture. At a more concrete level, our key findings can be summed up as follows.

First, participants' migration motivations do indeed reflect most, if not all, of the defining characteristics of liquid migration, namely temporariness, intentional unpredictability, and openness to diverse spatial and social mobilities (Engbersen and Snel 2013). These flexible space-time movements were often seen as a strategic tool for maximising opportunities, above all those which are constitutive of key youth transitions from education to work, from unemployment to 'any' job and subsequently, if all goes well, to a 'better' and even an 'ideal' job (Parutis 2011). The ultimate goal for many was to use these mobile youth transitions as a step towards more grounded, adult lives (Bygnes and Erdal 2017). Then, Brexit came as a political rupture and took away the privilege of future free movement, thereby threatening not only the positivity of a mind-set of intentional unpredictability but also the aspiration for a longer-term stability in the UK in the future.

Second, a political 'rupture' such as that brought about by the 2016 referendum not only reconfigures mobilities and the meaning migrants attached to these; it is a profoundly affective event. Brexit was variously felt and narrated as a 'punch', a 'hit', an 'earthquake' or a 'shock'. This is all the more intriguing if we recall that our research took place in 'Europhile' London and its surrounding areas, including Brighton, where large majorities voted 'remain.' By following the recommendation of Antonsich and Skey (2016) to further interrogate historically uneven power formations, we were able to expose some of the embedded national, ethnic and cultural hierarchies of privilege, value and desirability ascribed to different European migrants. These differences are perpetuated and intensified between the desirable whiteness of 'old' or 'West' Europeans versus the 'Eastern' newcomers, seen as poorer and rougher, coming from more economically backward countries of origin. However, in the case of the Irish, counterintuitively to their legal position but in line with a historical legacy of racialisation of Irish migrants in the UK (see McDowell 2007), the affective impact of Brexit emphasised their European migrant identity and global solidarity with other migrants in the UK.

Third, de Certeau's (1984: 19-20) definition of a spatial tactic as 'a calculated action determined by the absence of a proper locus [and through being] less visible' was at the core of opportunities created through 'liquid migration' and relatively open borders. By registering and controlling (i.e. 'solidifying') migrants in a soon-to-emerge post-Brexit Britain, they will be both located and made more visible. Accordingly, migrants' tactics are likely to change. Those working migrants who would prefer to remain in the UK said they would adjust and adapt, even if they face legal hardships in terms of visas and special permits, or socio-cultural challenges in terms of more hostile attitudes towards migrants. Young migrant workers expressed trust in their employers who would support and possibly 'fight' for their rights to remain in the UK. Many categories of UK employers - in farming, industry, the health and care sectors, and several other service activities - have expressed severe concerns about being able to fill their labour needs if immigration from the EU is choked off. This aspect opens up novel pathways for future research concerned with understanding how solidarity between workers and employers operates under various political atmospheres in the longer run.

Fourth, migrants' future plans reveal further diversification of mobilities and uncertainties related to settlement. Notably, migrants not only consider staying in the UK or going 'back' to their home country, but also moving elsewhere in Europe or even further afield. Those willing to adapt and remain in Britain may adopt 'micro-tactics of belonging' (Robinson 2002: 37) in home-making or negotiating distinctive notions of belonging (Scott 2013). Through this notion, future research could further our understanding of the tactical 
steps of migrants that are linked to strengthening belonging to the UK beyond formal and legal statuses.

\section{References}

Anderson B. 2012. Affect and biopower: towards a politics of life. Transactions of the Institute of British Geographers 37: 28-43.

Anderson B. 2016. Neoliberal affects. Progress in Human Geography 40: 734-753.

Antonsich M, Skey M. 2016. Affective nationalism: issues of power, agency and method. Progress in Human Geography. DOI: 10.1177/0309132516665279.

Bartolini L, Gropas R, Triandafyllidou A. 2016. Drivers of highly skilled mobility from southern Europe: escaping the crisis and emancipating oneself. Journal of Ethnic and Migration Studies. DOI: 10.1080/1369183X.2016.1249048.

Bauman Z. 2000. Liquid Modernity. Polity: Cambridge.

Blossfield HP, Klijzing E, Mills M, Kurz K. eds. 2006. Globalization, Uncertainty and Youth in Society. Routledge: London.

Bygnes S, Erdal MB. 2017. Liquid migration, grounded lives: considerations about future mobility and settlement among Polish and Spanish migrants in Norway. Journal of Ethnic and Migration Studies 43: 102-118.

Closs Sephens A. 2016. The affective atmospheres of nationalism. Cultural Geographies 23(2): 181-198.

Conti F, King R. 2015. Of mentalità and raccomandazione: comparing the emigration and internal migration of Italian graduates. Studi Emigrazione 197: 121-140.

de Certeau M. 1984. The Practice of Everyday Life. University of California Press: Berkeley.

Du Bois-Reymond M, Lopez-Blasco A. 2003. Yo-you transitions and misleading trajectories: towards integrated transition policies for young adults in Europe. In Young People and Contradictions of Inclusion: Towards Integrated Transition Policies in Europe, Lopez-Blasco A, McNeish W, Walther A (eds). Policy Press: Oxford.

Engbersen G, Snel E. 2013. Liquid migration: dynamic and fluid patterns of post accession migration. In Mobility in Transition: Migration Patterns after EU Enlargement, Glorius B, Grabowska-Lusinska I, Rindoks A (eds). Amsterdam: Amsterdam University Press; 21-40.

Eurostat 2016. Youth unemployment in the EU under 25 years of age, 2015. Available: http://ec.europa.eu/eurostat/statistics-

explained/index.php/Unemployment_statistics\#Youth_unemployment_trends

File:Table 3 unemployment rates by age and gender new.PNG

Favell A. 2008. Eurostars and Eurocities. Blackwell: Oxford.

Favell A, Nebe T. 2009. Internal and external movers: East-West migration and the impact of EU Enlargement. In Pioneers of European Integration: Citizenship and Mobility in the EU, Recchi E, Favell A (eds). Edward Elgar: Cheltenham; 205-223.

Fox JE, Moroşanu L, Szilassy E. 2012. The racialization of the new European migration to the UK. Sociology 46: 680-695.

Harney N, Baldassar L. 2006. Italian diasporas share the neighbourhood. Modern Italy 11: 3-7.

Hörschelmann K. 2011. Theorising life transitions: geographical perspectives. Area 43: 378383.

King R, Arbuckle L. 1992. A note on the Irish in Rome. Irish Geography 25: 188-194.

King R, Andall J. 1999. The geography and economic sociology of recent immigration to Italy. Modern Italy 4: 135-158. 
King R, Shuttleworth I. 1995. The emigration and employment of Irish graduates: the export of high-quality labour from the periphery of Europe. European Urban and Regional Studies 2: 21-40.

King R, Lulle A, Parutis V, Saar M. 2017. From peripheral region to escalator region in Europe: young Baltic graduates in London, European Urban and Regional Studies (accepted for publication).

Kosic A, Triandafyllidou A. 2003. Albanian immigrants in Italy: migration plans, coping strategies and identity issues. Journal of Ethnic and Migration Studies 29: 997-1014.

Koskela K. 2014. Boundaries of belonging: highly skilled migrants and the migrant hierarchy in Finland. Journal of Finnish Studies 17: 19-41.

Lundahl L, Olofsson J. 2014. Guarded transitions? Youth trajectories and school-to-work transition policies in Sweden. International Journal of Adolescence and Youth 19: 1934.

MacEinri P. 1989. The new Europeans: the Irish in Paris today. In Emigration, Employment and Enterprise, Mulholland J, Keogh D (eds). Hibernian University Press: Cork; 5880 .

McDowell L. 2007. Constructions of whiteness: Latvian women workers in post-war Britain. Journal of Baltic Studies 38: 85-107.

McDowell L. 2009. Old and new European economic migrants: whiteness and managed migration policies. Journal of Ethnic and Migration Studies 35: 19-36.

Moreh C, McGhee D, Vlachantoni A, McGowan T. 2016. Should I stay or should I go? Strategies of EU citizens living in the UK in the context of the EU referendum. Southampton: ESRC Centre for Population change, Briefing Paper 35.

Merriman P, Jones R. 2016. Nations, materialities and affects. Progress in Human Geography, DOI: 10.1177/0309132516649453.

Militz E, Schurr C. 2016. Affective nationalism: banalities of belonging in Azerbaijan. Political Geography 54: 54-63.

ONS 2016a. Office of National Statistics, UK. Dataset: Population of the United Kingdom by Country of Birth and Nationality, 25 August 2016. Available:

https://www.ons.gov.uk/peoplepopulationandcommunity/populationandmigration/inte rnationalmigration/datasets/populationoftheunitedkingdombycountryofbirthandnation ality

ONS 2016b. Office of National Statistics, UK. Table 1.3. Overseas-born population in the UK.

Parutis V. 2011. White, European, and hardworking: East European migrants' relationships with other communities in London. Journal of Baltic Studies 42: 263-288.

Scott D. 2013. Negotiated denizenship: foreign nationals' tactics of belonging in a Cape Town township. Social Dynamics 39: 520-535.

Scott JC. 1985. Weapons of the Weak: Everyday Forms of Peasant Resistance. New Haven, CT: Yale University Press.

Snel E, Staring R. 2001. Poverty, migration, and coping strategies: an introduction. Focaal European Journal of Anthropology 38: 7-22.

Tintori G, Romei V. 2017. Emigration from Italy after the crisis: the shortcomings of the brain drain narrative. In South-North Migration of EU Citizens in Times of Crisis, Lafleur J-M, Stanek M (eds). SpringerOpen; 49-64.

Trenz H-J, Triandafyllidou A. 2016. Complex and dynamic integration processes in Europe: Intra EU mobility and international migration in times of recession. Journal of Ethnic and Migration Studies, DOI: http://dx.doi.org/10.1080/1369183X.2016.1251013 
Walther A, Plug W, Du Bois-Reymond M, Chisolm L. 2006. Transitions from school to work in Europe: destandardization and policy trends. New Directions for Child And Adolescent Development 11: 77-90.

Wetherell M. 2013. Feeling rules, atmospheres and affective practice: some reflections on the analysis of emotional episodes. In Privilege, Agency and Affect. Understanding the Production and Effects of Action, Maxwell C, Aggleton P (eds). London and New York: Palgrave; 221-239.

Worth N. 2009. Understanding youth transition as a 'becoming': identity, time and futurity. Geoforum 40: 1050-1060. 